Proc. Estonian Acad. Sci. Biol. Ecol., 2004, 53, 1, 25-36

\title{
In situ and satellite investigations of optical properties of the ice cover in the Baltic Sea region
}

\begin{abstract}
Helgi Arst ${ }^{*}$ and Liis Sipelgas
Marine Systems Institute, Tallinn Technical University, Akadeemia tee 21, 12618 Tallinn, Estonia

Received 14 November 2003, in revised form 16 December 2003

Abstract. Possibilities of describing the spatial variation and properties of the ice cover in water bodies by simultaneous in situ and satellite measurements were studied. In 2000-03 a field programme on the structure and optics of ice and snow was performed in six Estonian and three Finnish lakes and in coastal waters of the Baltic Sea. Additionally properties and development of the ice cover in the Baltic Sea during winter 2002/03 were estimated relying on the data of the Moderate Resolution Imaging Spectroradiometer (MODIS), installed on the satellites Terra and Aqua. The surface albedo of the water bodies varied from about $95 \%$ for fresh snow to $19-22 \%$ for slush or the thin water layer on the ice. The vertically averaged diffuse attenuation coefficient of ice for brackish water Santala Bay exceeded considerably that for lakes. It was demonstrated that MODIS images give rather detailed information on ice conditions, which makes it possible to distinguish snow covered fast ice from new and melting ice, and also to detect the relative changes of surface albedo.
\end{abstract}

Key words: wintertime water bodies, optical properties of ice cover, albedo, remote sensing of ice.

\section{INTRODUCTION}

Snow and/or ice cover are important factors in the formation of the weather and climate not only in polar but also in sub-polar regions. Snow and ice are products of cold weather and precipitation, and therefore vary widely in their thickness and other properties from the fresh stages in autumn to spring melting season as well as from year to year (Michel \& Ramseier, 1971; Perovich, 1998; Granberg, 1998; Leppäranta et al., 2003). It has been shown also that the properties of ice cover affect phytoplankton photosynthesis in water (Fritsen \& Priscu, 1999). An important part of the investigations is the optics of ice and snow: albedo, light attenuation coefficient of ice cover, and under-ice light field. Data on the optical

*Corresponding author, helarst@online.ee 
properties and radiative transfer in the system "snow/ice cover + water" are necessary for remote sensing models and for investigating the growth of phytoplankton in early spring. Another important issue is the description of the spatial distribution of ice cover and its properties for large territories (e.g. for the Baltic Sea) for estimation and prognosis of ship traffic conditions in winter. Therefore it is necessary to know (1) the generation or melting of ice cover in different regions, (2) the dynamics of ice cover (movement of the ice masses under the influence of wind and drifts), and (3) ice types in different regions. Here satellite remote sensing results are a powerful tool for global mapping of the sea ice extent, type, and temperature.

In 2000-03 we performed a lake field programme on the structure and optics of ice and snow of Finnish and Estonian lakes. For comparison, a brackish water site from the Gulf of Finland (Santala Bay) was added. The data include the concentrations of optically active substances (OAS) in ice and under-ice water, the spectra of beam attenuation coefficient for filtered and unfiltered water (for ice they are determined from meltwater derived from ice), and the values of quantum irradiance in the photosynthetically active region (PAR) of the spectrum (400-700 nm) above and below the ice cover. Using these data we analysed the ice structure (including the formation of sublayers in the ice cover), determined the amount of OAS, and described under-ice light field (published in Leppäranta et al., 2003 and Erm et al., 2003). The present study is focused on optical characteristics of the system "snow + ice cover on the water" using in situ as well as satellite measurement data.

We investigated the properties and spatial development of the ice cover in the Baltic Sea during winter 2002/03 relying on the data of the Moderate Resolution Imaging Spectroradiometer (MODIS), installed on the satellites Terra and Aqua. As an example, the analysis of two images corresponding to 20 February 2003 and 28 March 2003 is shown in the present paper. The possibilities of distinguishing between the different ice types and estimating the spatial variation of surface reflectance by satellite data were studied.

Note that the ground level and satellite studies were not planned as one joint project. For this reason the respective study sites and times are different. However, the results obtained from in situ measurements obviously help to interpret the satellite data.

\section{MATERIALS AND METHODS}

The in situ basic data consist of irradiance measurements above and under ice cover, integrated over the PAR band (400-700 nm). A quantum sensor (LI 192 SA from LI-COR), providing quantum irradiance in $\mu \mathrm{mol} \mathrm{s}^{-1} \mathrm{~m}^{-2}$, was used. The fieldwork was done in winters 2000-03 in six Estonian and three Finnish lakes and in one brackish water site, Santala Bay, in the Gulf of Finland (Table 1). The measurements were made mostly between $10 \mathrm{a} . \mathrm{m}$. and $3 \mathrm{p} . \mathrm{m}$., and the solar altitude was from about $15^{\circ}$ in January to about $30^{\circ}$ in March. The under-ice light 
Table 1. Water bodies studied in the winters of 2000-03 (typical values of Secchi depth, $z_{\mathrm{s}}$, in the ice-free period are also shown)

\begin{tabular}{|c|c|c|c|c|c|}
\hline Water body & Latitude & Longitude & Limnological type & $\begin{array}{c}\text { Typical } \\
z_{\mathrm{s}}, \mathrm{m}\end{array}$ & Years \\
\hline \multicolumn{6}{|c|}{ Repeated measurements } \\
\hline Santala Bay & $59^{\circ} 55^{\prime} \mathrm{N}$ & $23^{\circ} 03^{\prime} \mathrm{E}$ & Oligotrophic/mesotrophic & 3 & 2000-02 \\
\hline L. Harku & $59^{\circ} 24^{\prime} \mathrm{N}$ & $24^{\circ} 37^{\prime} \mathrm{E}$ & Hypertrophic & $0.3-1$ & $2000-02$ \\
\hline L. Maardu & $59^{\circ} 26^{\prime} \mathrm{N}$ & $24^{\circ} 58^{\prime} \mathrm{E}$ & Dyseutrophic & $2.5-3.5$ & $2000-03$ \\
\hline L. Ülemiste & $59^{\circ} 24^{\prime} \mathrm{N}$ & $24^{\circ} 46^{\prime} \mathrm{E}$ & Hypertrophic & $0.7-1.5$ & 2000-02 \\
\hline \multicolumn{6}{|c|}{ Episodic measurements } \\
\hline L. Paukjärv & $59^{\circ} 23^{\prime} \mathrm{N}$ & $25^{\circ} 42^{\prime} \mathrm{E}$ & Oligotrophic & $4.5-6.5$ & 2000 \\
\hline L. Äntu Sinijärv & $59^{\circ} 05^{\prime} \mathrm{N}$ & $26^{\circ} 17^{\prime} \mathrm{E}$ & Alkalitrophic & $13-15$ & 2003 \\
\hline L. Nohipalu Valgjärv & $58^{\circ} 00^{\prime} \mathrm{N}$ & $27^{\circ} 21^{\prime} \mathrm{E}$ & Oligotrophic/mesotrophic & $3-7$ & 2003 \\
\hline L. Lammi Pääjärvi & $61^{\circ} 03^{\prime} \mathrm{N}$ & $25^{\circ} 07^{\prime} \mathrm{E}$ & Mesohumic & $1.5-3$ & 2003 \\
\hline L. Valkeakotinen & $61^{\circ} 14^{\prime} \mathrm{N}$ & $25^{\circ} 04^{\prime} \mathrm{E}$ & Dystrophic & $0.8-1.1$ & 2003 \\
\hline L. Ormajärvi & $61^{\circ} 06^{\prime} \mathrm{N}$ & $24^{\circ} 57^{\prime} \mathrm{E}$ & Eutrophic & 3 & 2003 \\
\hline
\end{tabular}

field is formed under the simultaneous influence of many factors: the values of incident irradiance (which depend on the solar altitude and synoptic conditions), the presence of snow on the ice cover, the thickness and optical properties of snow and ice, and optical properties of under-ice water.

We chose for analysis the following characteristics produced from the irradiance data:

- albedo of the ice (or snow) surface $(A)$,

- averaged vertical attenuation coefficient of light in the ice cover $\left(K_{\mathrm{d}, \mathrm{i}}\right)$,

- the ratio of irradiance just under the snow/ice cover to the value of incident irradiance $(T)$.

Note that all results presented in this paper were obtained as integrals over the PAR region of the spectrum (400-700 nm); the index "PAR" was suppressed for brevity.

For the irradiance measurements under ice cover, a special device (including quantum sensor LI-192 SA) was constructed, described in detail in Leppäranta et al. (2003). The device is lowered into the water through a $30 \mathrm{~cm}$ hole in the ice and fastened on a tripod. After that consoles are positioned horizontally using cords. The desired measurement depth can be selected by changing the length of the probe and the inclination of the legs of the tripod. The system allows irradiance measurements to about $1 \mathrm{~m}$ in the horizontal direction from the vertical of the ice hole and down to a depth of 1.5-2 m. In the water the instruments were first lowered and then brought back to the surface, and irradiances were measured in both directions. In the case of snow on the ice, the snow was removed and the measurements were repeated. The values of albedo for the PAR region were calculated from the air measurement data (obtained by means of two LI-192 SA). A datalogger LI-1400 was applied for the recording of the measurement results. 
Surface albedo $(A)$ was calculated as the ratio of upwelling irradiance $\left(q_{\mathrm{u}}\right)$ to downwelling irradiance $\left(q_{\mathrm{d}}\right)$, measured at the height of $1 \mathrm{~m}$ :

$$
A=q_{\mathrm{u}}(\text { air }) / q_{\mathrm{d}}(\text { air }) .
$$

As is known, the spectral values of the diffuse attenuation coefficient $K_{\mathrm{d}, \mathrm{w}}$ for the vertically homogeneous water layer from the depth $z_{1}$ to the depth $z_{2}$ can be calculated as follows (based on an exponential decrease of irradiance with depth):

$$
K_{\mathrm{d}, \mathrm{w}}\left(z_{1}, z_{2}\right)=-\frac{1}{z_{2}-z_{1}} \ln \left(\frac{q_{\mathrm{d}}\left(z_{2}\right)}{q_{\mathrm{d}}\left(z_{1}\right)}\right) .
$$

When the water in the layer between $z_{1}$ and $z_{2}$ is vertically heterogeneous, $K_{\mathrm{d}, \mathrm{w}}\left(z_{1}, z_{2}\right)$ is the average coefficient for this layer. For the surface layer $q_{\mathrm{d}}\left(z_{1}\right)=(1-A) q(\mathrm{inc})$, where $q(\mathrm{inc})$ is the incident irradiance.

In the ice cover the attenuation coefficient is not constant since there are sublayers of different optical properties. However, the attenuation of light in the ice cover can be estimated using the vertically averaged diffuse attenuation coefficient of light:

$$
K_{\mathrm{d}, \mathrm{i}}(D)=-\frac{1}{D} \ln \left(\frac{q_{\mathrm{d}}(D)}{(1-A) q(\mathrm{inc})}\right),
$$

where $D$ is the thickness of the ice cover and $q$ (inc) is the incident solar irradiance onto the upper ice surface.

We had no possibilities of determining the value of $K_{\mathrm{d}}$ for the system "snow + ice" (two-layer system), because for this the irradiance value at the lower surface of the snow layer has to be known (different thicknesses and optical properties of snow and ice layers). However, some estimations can be made calculating the ratio $T=q_{\mathrm{d}}(D) / q_{\mathrm{d}}$ (inc). It shows which part of the incident irradiance penetrates through the system "snow + ice" (with or without snow). Note that the value of $T$ depends not only on the light attenuation properties of snow and ice, but also on the albedo of the surface.

\section{SATELLITE IMAGES}

For investigating the spatial distribution of the ice cover microwave instruments are usually used. However, for measuring the spectral reflectance of the surface (needed for distinguishing different ice types and for analysis of energy exchange between the ocean and the atmosphere) multispectral radiometers are preferable (Riggs et al., 1999). 
We used multispectral radiometer MODIS data, whose availability and spatial resolution are the most suitable for our studies. This data complex has 36 spectral bands ranging in wavelength from 400 to $14400 \mathrm{~nm}$, from which we used channel 1 (band 620-670 nm) and channel 2 (841-846 nm). The spatial resolution for channels 1 and 2 is $250 \mathrm{~m}$, for channels $3-7$ it is $500 \mathrm{~m}$, and for other channels, $1000 \mathrm{~m}$. The temporal coverage of satellites where a MODIS instrument is installed enables us to receive $2-4$ images per day. From these images we can choose the most suitable (if possible, cloud-free) case. Global ice products with $1000 \mathrm{~m}$ resolution are produced by the National Snow and Ice Data Centre (NSDIC) daily and as 8-day composite sea-ice cover maps. The map products are available also at $0.05^{\circ}(\approx 5.6 \mathrm{~km})$ resolution for climate modelling. The standard algorithm is based on the Normalized Difference Snow Index (NDSI) modified for sea ice to distinguish it from the open water, relying on reflective and thermal characteristics. All products are archived at the NSDIC in Boulder, CO. In these products the influence of clouds is eliminated by using the standard "cloud mask" product for MODIS data. However, Hall et al. (2002) showed that the cloud mask (Ackerman et al., 1998) as it is used currently in the MODIS standard products tends to overestimate the cloud cover. Thus, a MODIS colour composite image gives a more realistic description of the ice cover (Hall et al., 2002). Therefore, we used MODIS data from channels 1 and 2 instead of the standard sea ice cover product. Images were geocorrected and, using calibration coefficients (added to each MODIS image), converted into reflectance at satellite level (Level 1 according to MODIS calibration), which we call "satellite reflectance" (no units).

\section{RESULTS AND DISCUSSION}

\section{Measurements in situ}

The dependence of albedo on surface conditions is shown in Table 2. We can see the decrease in the values of snow albedo from very fresh snow to old and melting snow. Naturally, the values of $A$ (snow) and $A$ (snow removed) differ from each other, but the numerical values of these differences vary in dependence on reflective properties of the ice cover and/or melting ice (as well as snow). In most cases $A$ (snow removed) exceeds 0.5 , which is systematically higher than $A$ (ice). It is explained not only by the transparency properties causing a dark "colour" of some types of ice and/or the melting ice (smaller scattering coefficients), but also by the fact that usually just below snow there is "snow ice" with a rather high albedo. Also cases of scabrous ice can occur, and then all the snow cannot be removed (some small part of snow will remain on the ice increasing its albedo).

According to Oceanographic Tables (1975) the albedo of fresh and dry snow is in the range $80-95 \%$, and it decreases with the aging of snow, the values $0.3-$ 0.4 being characteristic of melting snow. For ice albedo this book presents only data for Arctic seas, where the value varies from 0.4 to 0.7 . However, these values obviously do not describe the PAR region, but the whole solar spectrum, where 
Table 2. Variations of the surface albedo of water bodies in wintertime obtained for the region $400-700 \mathrm{~nm}$ from measurements in 2000-03

\begin{tabular}{lc}
\hline \multicolumn{1}{c|}{ Description of the surface } & Albedo \\
\hline Fresh snow & $0.91-0.95$ \\
Snow & $0.80-0.90$ \\
Old snow & $0.67-0.73$ \\
Melting snow & 0.63 \\
Hoarfrost on the ice & $0.51-0.58$ \\
Ice when snow is removed & $0.37-0.70$ \\
Gray or dark grey ice & $0.20-0.48$ \\
Melting ice & $0.23-0.29$ \\
Remains of slush on the ice & 0.22 \\
Thin water layer on the ice & 0.19
\end{tabular}

the spectra fall after $600 \mathrm{~nm}$, in particular when the surface is wet. Kaup (1995) measured integral albedo in six lakes in East Antarctica and obtained 0.74-0.90 for snow and 0.13-0.59 for ice. It is interesting that during the Antarctic winter the lake ice was mostly devoid of snow and rather transparent $(A=0.17-0.40)$, but in the melting period the ice was whitish, with the albedo of $0.44-0.52$. Rasmus (2003) measured the spectral albedo of Antarctic snow; in the region of $400-700 \mathrm{~nm}$ it was $0.90-0.96$, and it decreased slowly towards greater wavelengths. Perovich (1998) gives the following typical values of $A$ : 0.87, 0.77, 0.70, and 0.30 respectively for snow, melting snow, ice, and melting ice, but for the PAR band he got about 0.90 for cold snow, 0.75 for cold bare ice, and 0.65 for melting snow. According to Ishikawa et al. (2003) the integral albedo measured in the Tvärminne biological station (Finland) was about 0.8 for snow, $0.30-0.35$ for thick ice, and $0.1-0.2$ for thin $(D<10 \mathrm{~cm})$ ice (the ice layer growing step by step was observed). Note that the surface layer properties vary very widely in snow and ice, in ways not so far quantified. Therefore quite different albedo values exist in the literature even for conditions that look similar.

Comparison of the data of Table 2 and Ishikawa et al. (2003) shows that in the Baltic Sea region thin (probably growing) and melting (covered with water or slush) ice give rather similar values of surface albedo. This has to be taken into account when interpreting satellite images with significantly changing albedo in this region.

The mean values of the light attenuation coefficient for ice cover calculated by Eq. 3 are presented in Fig. 1. We can see that $K_{\mathrm{d}, \mathrm{i}}$ for the lakes is considerably lower than that for Santala Bay. It can be explained by the fact that the brackish ice contains brine pockets where phytoplankton often grows. This leads to an increase in the absorption of light in the ice. Also in brackish waters the ice captures more dissolved matter than in lakes (Leppäranta et al., 2003).

It is well known that snow is the main factor in the attenuation of light penetrating through snow + ice cover (Reinart, 2000; Leppäranta et al., 2003). The ratio $T=q_{\mathrm{d}}(D) / q_{\mathrm{d}}$ (inc) and the corresponding thickness of snow and ice are shown in Fig. 2. The values of $T$ (snow removed) vary in the range 3.5-58\%, 


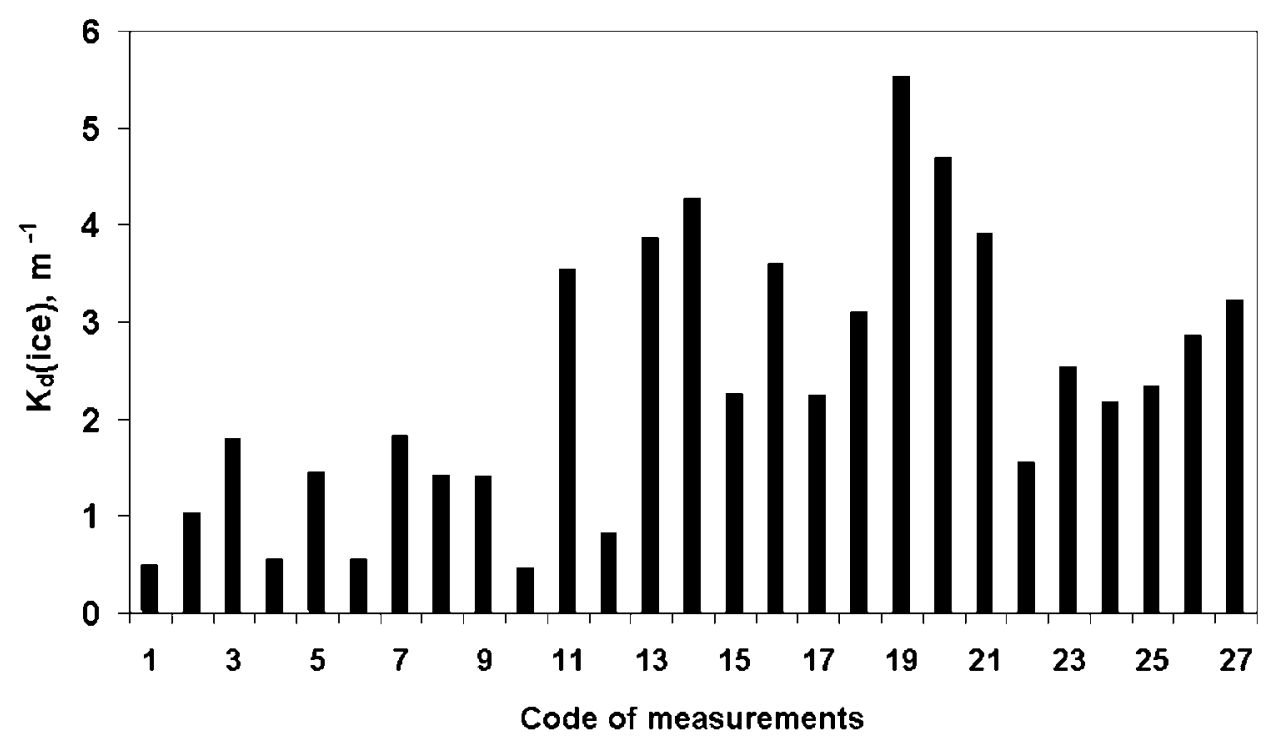

Fig. 1. Vertically averaged light attenuation coefficient of ice cover in lakes (Nos. 1-12) and in Santala Bay (Nos. 13-27).

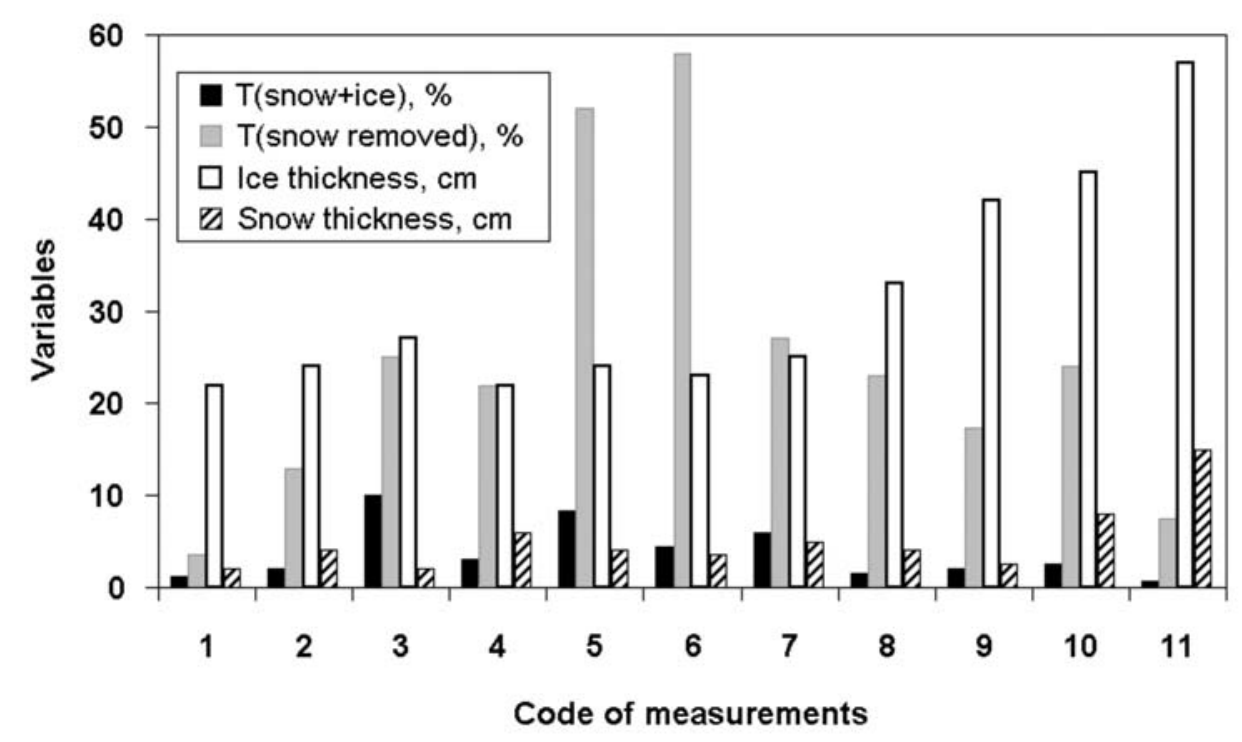

Fig. 2. Values of $T=q_{\mathrm{d}}(D) / q_{\mathrm{d}}$ (inc) with and without snow cover and the corresponding thickness of snow and ice (only for lakes). 
being 2.5-14 times higher than $T$ (snow + ice). The concrete values of $T$ depend on the albedo and thickness of ice and snow as well as on their optical properties. As noted above, the amount of light energy under the ice is an important factor for the growth of phytoplankton in the water. By Leppäranta et al. (2003) even depletion of dissolved oxygen in the water may occur under a thick snow + ice cover.

\section{IMAGE ANALYSIS}

The image obtained on 20 February 2003 (Fig. 3) shows areas of different colour that represent the different reflectance values in the range of band 1 . Simultaneous in situ studies for determination of ice type and thickness were performed during the field survey to the Gulf of Riga. The light blue areas (reflectance value 0.161-0.216) on the MODIS image (Fig. 3) correspond to fast snow covered ice with a thickness of 60-70 cm, the dark blue areas (reflectance value $0.0435-0.13$ ) correspond to bare ice with a thickness of $30-35 \mathrm{~cm}$ (field measurement sites are shown in the figure). So, the reflectance data recorded by the MODIS instrument (band 1) enable to distinguish the areas with different ice types. On average the reflectance of bare ice is about $46 \%$ of that for snow covered fast ice (the difference between the two types is 54\%). It is in good correspondence with the estimations by Riggs et al. (1999) who found the difference between the surface reflectance of new and snow covered ice to be approximately $60 \%$ (they used the spectral data for the same band measured by MODIS Airborne Simulator). Estimation of this difference on the basis of our ground measurements (Table 2) yields the same average result.

Comparison of ice types with the MODIS data was also done on 28 March 2003 (Fig. 4). At that time the ice cover was already melting in the Väinameri area, but in Pärnu Bay the ice was still up to $60 \mathrm{~cm}$ thick and partly snow covered. The difference in the reflectance values between the fast snow covered ice (reflectance $0.19-0.22$, from image on 20 February) and the melting ice (reflectance $0.1-0.13$ from image on $28 \mathrm{March}$ ) was 0.43 , the melting ice having lower reflectance. By our ground measurements (Table 2) the average albedo of melting ice was 0.37 of that for the old snow cover (i.e. to some extent different from the result by MODIS image). This can be caused by the different optical properties of snow (fresh and clean or polluted) and also the stage of melting at which the ice was. Also the differences between optical properties of lake ice and sea ice can be of influence.

We can expect that the satellite reflectance measured in conditions of ice/snow cover is in good correspondence with the values of surface albedo; consequently, their spatial variations can describe the change of albedo (in relative units). Of course, the atmosphere affecting the satellite results can cause some inadequacy of the images. However, the images used for ice investigations are mostly cloudfree and are taken during a short time (the influence of the atmosphere is almost equal on the territory of one image). For the same reason the spatial variation of downwelling irradiance (Eq. 1) in this territory is small. 


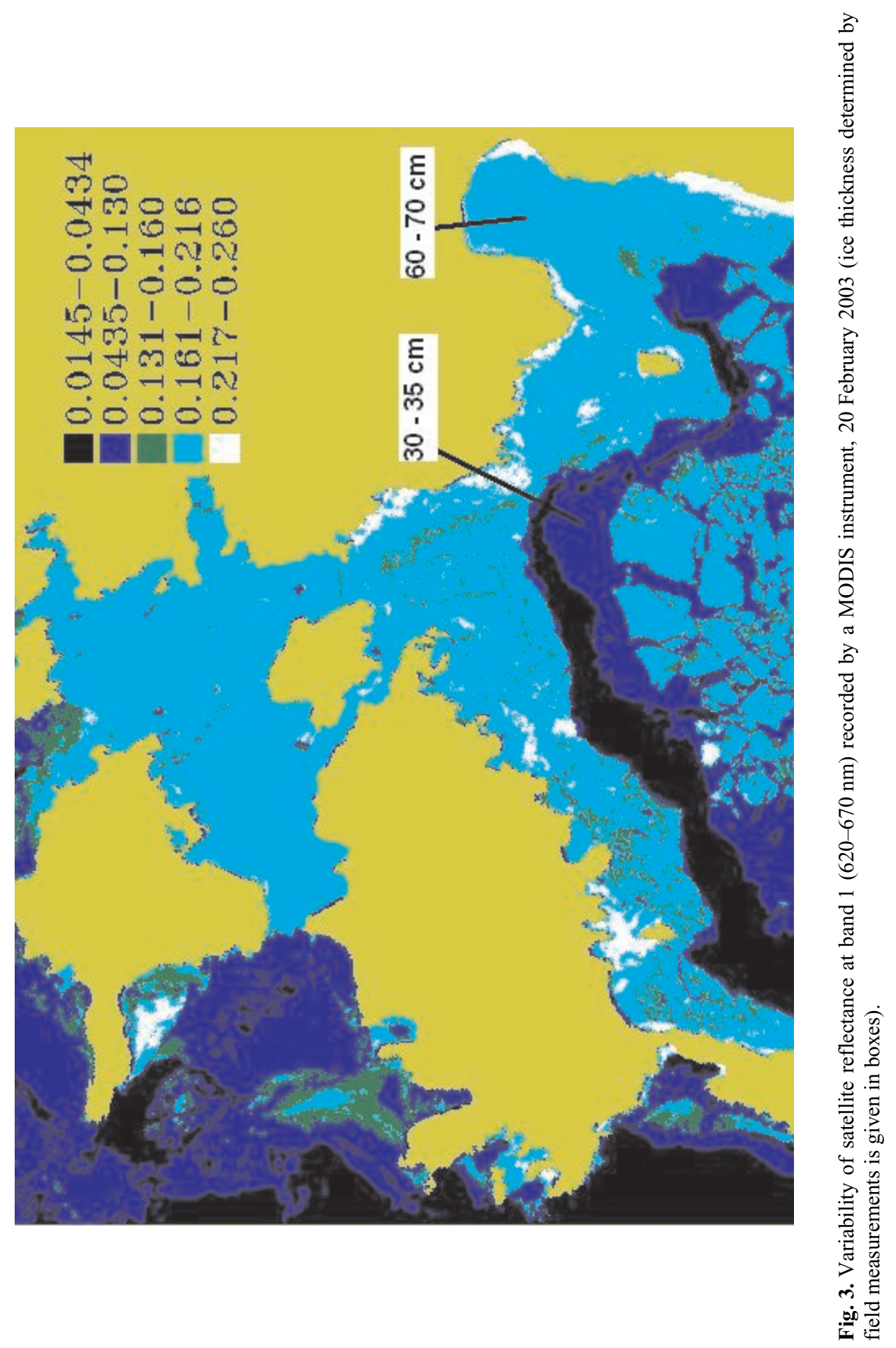




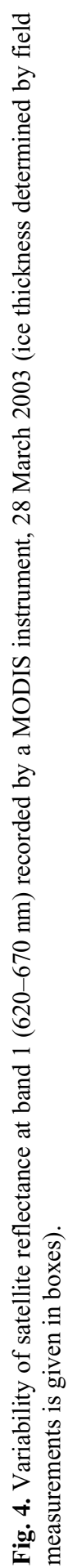




\section{CONCLUSIONS}

Our results show that in wintertime the surface albedo of water bodies can vary in great limits, from about 0.95 for fresh snow to $0.19-0.22$ for slush or a thin water layer on the ice.

The vertically averaged diffuse attenuation coefficient of ice was considerably lower for lakes than for Santala Bay. This can be explained mainly by the fact that the brackish ice contains brine pockets where phytoplankton often grows, which leads to increasing absorption of light in the ice.

After removing the snow cover from the ice the ratio $T=q_{\mathrm{d}}(D) / q_{\mathrm{d}}$ (inc) varied in the range $3.5-58 \%$, being $2.5-14$ times higher than the ratio before the snow was removed. The concrete values of $T$ depend on the albedo and thickness of ice and snow as well as on their optical properties.

Our results indicate that relying on MODIS data it is possible not only to describe the spatial variation of the ice cover, but also to distinguish snow covered fast ice from new and melting ice. The images give us rather detailed information on ice conditions over the sea and also in coastal waters.

The "satellite reflectance" values obtained from MODIS images in clear sky conditions seem to be in good correspondence with the values of ice/snow cover albedo in relative units, and describe its spatial variations.

Further studies where satellite and ground level measurements are performed simultaneously should be useful for assessing the relationships between satellite reflectance and ice-covered surface albedo.

\section{ACKNOWLEDGEMENTS}

The authors thank the Estonian Science Foundation (grant No. 3613) for financial support. We are also grateful to Anu Reinart and Ants Erm for assistance in fieldwork and to Tarmo Kõuts for providing the ENVI software for processing the satellite images.

\section{REFERENCES}

Ackerman, S. A., Strabala, K. I., Menzel, P. W. P., Moeller, C. C. \& Gumley, L. E. 1998. Discriminating clear sky from clouds with MODIS. J. Geophys. Res., 103 (D24), 3214132157.

Erm, A., Reinart, A., Arst, H., Sipelgas, L. \& Leppäranta, M. 2003. Optical properties of lake and sea ice. In Rep. Ser. Geophys., No 46, 93-100. University of Helsinki, Hokkaido University, Helsinki.

Fritsen, C. H. \& Priscu, J. C. 1999. Seasonal change in the optical properties of the permanent ice cover on Lake Bonney, Antarctica: consequences for lake productivity and phytoplankton dynamics. Limnol. Oceanogr., 44(2), 447-454.

Granberg, H. B. 1998. Snow cover on sea ice. In Physics of Ice-covered Seas (Leppäranta, M., ed.), pp. 605-651. Helsinki University Printing House. 
Hall, D. K., Riggs, G., Salomonson, N. E., DiGirolamo, N. E. \& Bayr, K. J. 2002. MODIS snowcover products. Remote Sens. Environ., 83, 181-194.

Ishikawa, N., Takizawa, A., Kawamura, T., Shirasawa, K. \& Leppäranta, M. 2003. Changes of the radiation property with sea ice growth in Saroma Lagoon and the Baltic Sea. In Rep. Ser. Geophys., No 46, 147-160. University of Helsinki, Hokkaido University, Helsinki.

Kaup, E. 1995. Solar radiation in water bodies. In The Schirmacher Oasis, Queen Maud Land, East Antarctica and Its Surroundings (Bormann, P. \& Fritsche, D., eds.), pp. 286-290. Perthes, Gotha.

Leppäranta, M., Reinart, A., Erm, A., Arst, H., Hussainov, M. \& Sipelgas, L. 2003. Investigation of ice and water properties and under-ice light field in fresh and brackish water bodies. Nord. Hydrol., 34(3), 245-266.

Michel, B. \& Ramseier, R. O. 1971. Classification of river and lake ice. Can. Geotechn. J., 8(13), 36-45.

Oceanographic Tables. 1975. Gidrometeoizdat, Leningrad (in Russian).

Perovich, D. K. 1998. The optical properties of the sea ice. In Physics of Ice-covered Seas (Leppäranta, M., ed.), pp. 195-230. Helsinki University Printing House.

Rasmus, K. 2003. The albedo of Antarctic snow. In Rep. Ser. Geophys., No 46, 73-78. University of Helsinki, Hokkaido University, Helsinki.

Reinart, A. 2000. Underwater light field characteristics in different types of Estonian and Finnish lakes. Diss. Geophys. Univ. Tartu, 11.

Riggs, A. G, Hall, K. D. \& Ackerman, S. A. 1999. Sea ice extent and classification mapping with the Moderate Resolution Imaging Spectroradiometer Airborne Simulator. Remote Sens. Environ., 68, 152-163.

\title{
Jääkatte optiliste omaduste uurimine in situ ja satelliitmõõtmiste abil Läänemere regioonis
}

\author{
Helgi Arst ja Liis Sipelgas
}

Kasutades in situ ja satelliitmõõtmisi, hinnati veekogude jääkatte optilisi omadusi, tüüpe ja ruumilist levikut. Aastail 2000-2003 viidi läbi välitööde programm Eesti ja Soome järvedel ja Santala lahel (Läänemeri). Kasutades satelliitsensori MODIS (Moderate Resolution Imaging Spectroradiometer) andmeid 2002/2003. aasta talve jaoks, uuriti jääkatte levikut ja jää omaduste muutlikkust Läänemerel. Jää/lumikatte albeedo varieerus $95 \%$ (värske lumi) ja 19-22\% (lörts või õhuke veekiht jää peal) vahel. Valguse difuusse nõrgenemiskoefitsiendi vertikaalselt keskmistatud väärtused Santala lahe jää jaoks ületasid tunduvalt selle koefitsiendi väärtusi järvejää puhul. Satelliitandmete töötlus näitas, et MODIS-e pildid võimaldavad hinnata jäätunud veealade eri tüüpe (lumega kaetud jää, noor jää, sulav jää jne), samuti jääkatte albeedo väärtusi ja muutlikkust (relatiivsetes ühikutes). 